\title{
Bacillus Subtilis as Self-Healing Agent in Cement Mortar: Combined and the Separate Effect of Bacteria and Calcium Lactate on Self-Healing Behavior in Cement Mortar
}

\author{
Sohail Muhammad $^{1 \mathrm{a}}$, Humair Ahmed Siddiqui, ${ }^{1,2}$, Muhammad Ishaque Abro ${ }^{3}$, Adil \\ Usmani $^{1 b}$, Muhammad Amjad Anwar Mallick ${ }^{1 c}$ \\ RECEIVED ON 20.03.2019, ACCEPTED ON 26.07.2019
}

\begin{abstract}
Cement mortar, which is one of the most useful materials for construction applications, can deteriorate its performance by developing cracks. In order to cope with this issue, the materials' scientist came forward with a unique biogeochemical phenomenon in which cement mortar can selfheal its crack autonomously using calcium carbonate precipitating bacteria and their feed. In this research, it was intended to study the separate and combined effect of Bacillus Subtilis (bacteria) and Calcium Lactate (feed) on the properties of conventional mortar. Cement mortars were made using conventional method and cast in the form of cylinders. Four types of samples were taken. Sample-N contains only cement and sand, Sample-B was made by addition of bacteria Bacillus Subtilis with sand and cement, Sample-C contains Calcium Lactate which is usually used as feed for Bacteria while the last sample ' $\mathrm{BC}$ ' have both Bacteria as well as Calcium Lactate. The samples were observed up to 44 days for their surface characteristics and compressive strength. The Sample-N and B did not show any remarkable change in their surface appearance with respect to curing time. Sample-C and BC did show the precipitation of $\mathrm{CaCO}_{3}$ but the Sample-C precipitation was stopped soon while for Sample-BC, the precipitation was continued for a longer time. The Sample-BC showed the highest compressive strength (approximately 17.57 MPa), followed by Sample-N (approximately 13.32 MPa), Sample-B (approximately 11.04 MPa) while Sample-C displayed lowest strength (approximately $2.75 \mathrm{MPa}$ ). This gives an idea that Calcium Lactate which acts as feed for bacteria has the negative effect on the strength if not consumed and converted into $\mathrm{CaCO}_{3}$.
\end{abstract}

Keywords: Self-Healing, Cement Mortar, Bacillus Subtilis, Calcium Lactate, Compressive Strength.

\section{INTRODUCTION}

Concrete structures are susceptible to crack development mainly due to early-age shrinkage and loading conditions. Scientific studies revealed that the service life and performance of concrete is reduced due to crack formation/growth, through which water, $\mathrm{Cl}^{-}$ions and $\mathrm{CO}_{2}$ gas penetrates resulting in the degradation of concrete and corrosion of reinforcement. Traditionally different methods like the use of polymeric fillers, were used to seal the crack, however, they were not entirely successful, mainly due to some factors like mismatch in thermal expansion properties of filler and concrete and weathering effects [1,2]. Different aspects of cement are studied in literature such as use of induction furnace slag as a

\footnotetext{
${ }^{1}$ Department of Materials Engineering, NED University of Engineering and Technology, Karachi, Sindh, Pakistan. Email: ${ }^{a}$ msohail@neduet.edu.pk, bengineeradilusmani@gmail.com, 1camjad.anwar13@gmail.com

${ }^{2}$ School of Engineering, Faculty of Science and Engineering, University of Waikato, Hamilton 3240, New Zealand. Email: ahumair@hotmail.com

${ }^{3}$ Department of Metallurgy and Materials Engineering, Mehran University of Engineering and Technology, Jamshoro, Sindh, Pakistan. Email: ishaque.abro@ @aculty.muet.edu.pk (Corresponding Author)

This is an open access article published by Mehran University of Engineering and Technology, Jamshoro under CC BY 4.0 International License.
} 
replacement of cement [3], use of wood waste to enhance the echo efficiency of cement [4], the role of steel fibers to enhance mechanical properties of concrete [5], cracking of clay beams that can replace concrete beams [6] and effect of treated wastewater on the strength of concrete [7].

The advancements in Materials Science and Concrete Technology had brought forward a unique solution to the complex problem of crack formation/growth in concrete structures. A new term "self-healing concrete" was coined to represent a biogeochemical phenomenon through which concrete can heal its crack autonomously, cutting edge research is going on to apply this technology [8-14]. This crack healing results in the enhancement of compressive strength, which is an added benefit along with the sealing of crack. This effect of seal healing is due to special types of bacteria (harmless and non-pathogenic), which can produce calcite (calcium carbonate) to fill up the crack. This type of concrete contains bacteria and their feed, as additional ingredients $[2,15]$.

Naturally, different microorganisms can precipitate calcite $[16,17]$ through a biogeochemical process by chemically altering their local environment [18]. In 1913 Drew first isolated such bacteria and named them "Bacterium Calcis" [19], after which many different bacteria were reported to be precipitated [20-23]. The selection of the right microorganisms (bacteria) for the healing purpose is broadly studied based on their nature, purpose and ability to withstand environmental conditions, however, as a general rule, the type of bacteria that can resist alkalinity and mechanical stress are best suited for the manufacturing of self-healing concrete. Jonker and Schlangen [24] used four strains of alkaliphilic spore-forming bacteria, namely Sporosarcina Pasteurii, Bacillus Cohnii. Bacillus Halodurans and Bacillus Pseudofirmus, while calcium lactate was used as their feed. Authors reported the selfhealing effect, however, the cost of making was higher than normal concrete. Similarly, Ghosh et al. [25] reported significant increase in compression strength by the use of Shewanella anaerobic microorganisms, however these microorganisms are safe for humans. In another study, Ramachandran [26] used Bacillus Pasteurii, which resulted in crack sealing, but no increase in strength was reported.

Bacteria of the bacillus (unicellular, prokaryotic, gram-positive genus) species have exactly the accurate characteristics that could be necessary for optimum healing of micro voids. Their spores can survive in the alkaline environment for decades in a dormant state, without food or oxygen. They will be active only when water and oxygen are added in the structure. Different species of the bacillus can be used for the purpose of healing of the micro voids. Strains of bacteria of genus Bacillus were found to thrive in highly alkaline condition. It was found that only the group of bacteria that were able to survive was the ones that grew in spores. These are namely Bacillus Pasturii, Bacillus Filla, Bacillus Cohni, Bacillus Subtilis and Bacillus Psedofirmus. Bacillus Subtilis also called the grass bacillus are the species that can be found easily in nature. It is basically a common soil bacterium. It can produce calcite precipitates on suitable media supplemented with a calcium-based source or a supplement [27, 28]. Bacillus Subtilis was used to induce calcite precipitation at a much faster rate. These bacterial spores can lie dormant for decades. Bacillus subtilis is a unicellular, prokaryotic, gram-positive genus, nonpathogenic, eco-friendly bacteria, that has a tendency to grow in spores and endures for couple of centuries [29, 30]. Khaliq et al. [31] studied the effect of different incorporation techniques for "Bacillus Subtilis", introduced in concrete. Different incorporation techniques do affect the magnitude of crack healing and compressive strength of concrete. However, they used a large amount of $18 \%$ of Calcium Lactate, which would increase the cost of construction. In order to make a self-healing concrete/cement mortar, it is essentially required to find the effects of different additional ingredients, like feed, bacteria, on the structure, performance and compressive strength of concrete/cement mortar. The results of such comparative study will not help in better understanding the biogeochemical phenomenon, but can also help in optimizing the properties of the final product. In the present study, separate and combined effects of calcium carbonate precipitating bacteria and its feed was studied in the conventional cement mortar.

\section{EXPERIMENTAL SETUP}

\subsection{Materials}

Bacillus Subtilis was sourced locally from Department of Microbiology, Karachi University and was grown

Mehran University Research Journal of Engineering and Technology, Vol. 40, No. 2, April 2021 [p-ISSN: 0254-7821, e-ISSN: 2413-7219] 
in the laboratory under suitable conditions. Calcium Lactate (Lab grade) was purchased from International laboratory USA, the details are listed in Table 1. Local supply of Ordinary Portland cement and Natural sand (fine aggregate) were used to make cement mortar, using tap water. All the glassware was chemically washed and dried before use. For any other laboratory work, double distilled water was used. Fig. 1(a-e) represents different raw materials used, while Fig. 2 (a-c) represents laboratory preparations of bacteria.

\begin{tabular}{|c|c|}
\hline \multicolumn{2}{|c|}{ Table 1: Calcium Lactate Properties } \\
\hline Product Name & Calcium Lactate, $98-103 \%$ BP USP \\
\hline Product Code & 1026762 \\
\hline CAS Number & $814-80-2$ \\
\hline Formula & 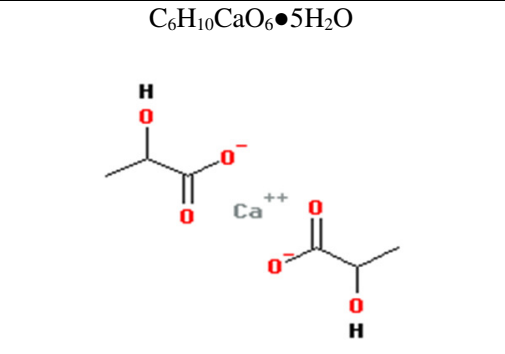 \\
\hline Synonym & $\begin{array}{l}\text { Propanoic acid, 2-hydroxy-, calcium salt } \\
\text { (2:1); lactic acid, calcium salt }(2: 1) ; 2- \\
\text { hydroxypropanoic acid calcium salt; calcium } \\
\text { lactate; calcium lactate (1:2); } \\
\text { calphosan;conclyte calcium; lactic acid, } \\
\text { calcium salt (2:1);2-hydroxy-propanoic acid } \\
\text { calcium salt (2:1) }\end{array}$ \\
\hline
\end{tabular}

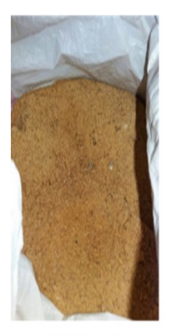

(a) Sand

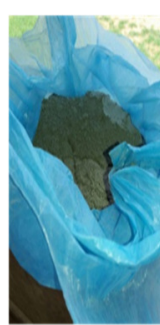

(b) Cement

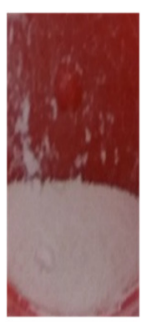

c) Calcium lactate

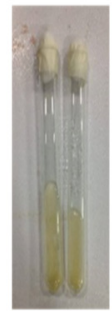

(d) Bacteria

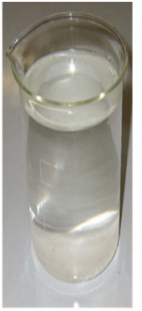

(e) Water

Fig. 1: Raw Materials used in Experiments

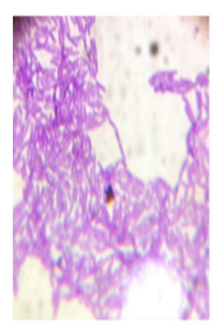

(a) Bacillus Subtilis at 100X

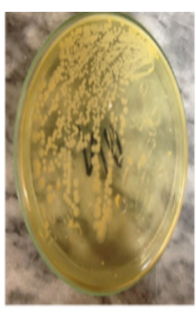

(b) Petri dish containing grown Bacteria

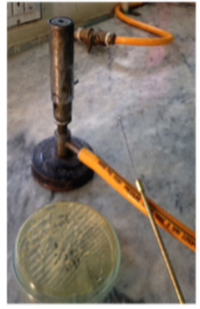

(c) Wire loop and Bunsen burne Ilsed tn nick harterial colnnier

Fig. 2: Bacterial Colonies Grown

\subsection{Fabrication of Cement Mortar Samples}

This study involved comparison of four (4) different types of samples, which are alphabetically coded for easy referencing in the paper. These are mentioned in Table 2. All 4 types of cement mortar samples were synthesized by the same procedure, as mentioned in Fig. 3, but the composition in each sample was different, as mentioned in Table 3 . The slurry was mixed properly to make the paste. The slurry was then poured into the molds, for casting the cement mortar samples of required shape and size. Piping PolyVinyl Chloride (PVC) pipes were used as the molds to cast cylindrical blocks as shown in F Finally, blocks were left for atmospheric curing as shown in Fig. 4 (a-d).

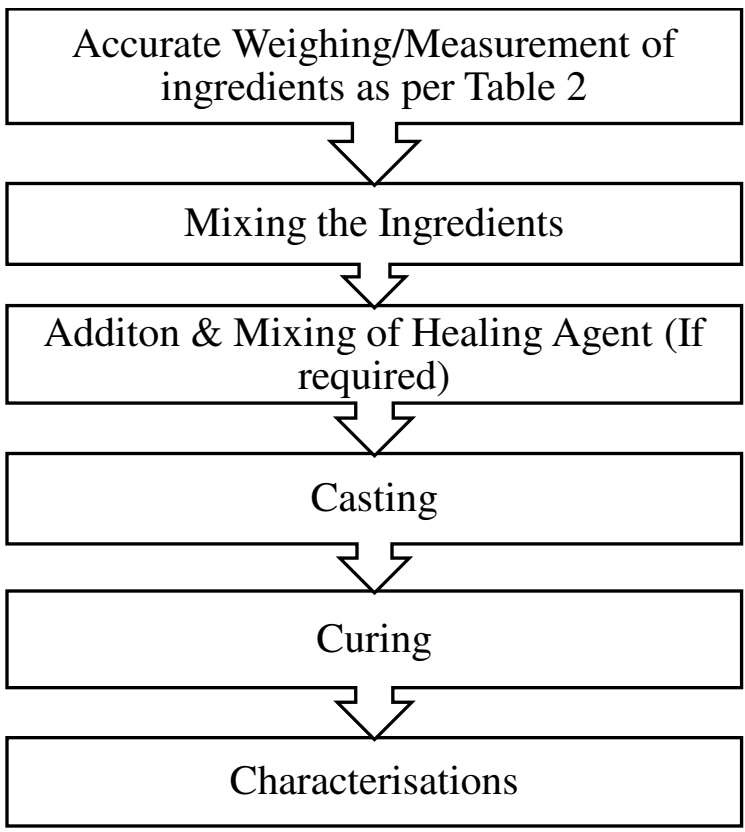

Fig. 3: Process Flow

\begin{tabular}{|c|c|c|}
\hline \multicolumn{3}{|c|}{ Table 2: Alphabetic Coding Of Samples } \\
\hline No. & Sample Name & $\begin{array}{c}\text { Alphabetic } \\
\text { Coding }\end{array}$ \\
\hline 1. & Conventional cement mortar & $\mathrm{N}$ \\
\hline 2. & $\begin{array}{c}\text { Bacterial Cement mortar, } \\
\text { contain bacillus subtilis }\end{array}$ & $\mathrm{B}$ \\
\hline 3. & $\begin{array}{c}\text { Calcium Lactate Containing } \\
\text { Cement mortar }\end{array}$ & $\mathrm{C}$ \\
\hline 4. & $\begin{array}{c}\text { Bacillus subtilis + Calcium } \\
\text { lactate containing cement } \\
\text { mortar }\end{array}$ & $\mathrm{BC}$ \\
\hline
\end{tabular}




\begin{tabular}{|c|c|c|c|c|}
\hline \multicolumn{5}{|c|}{ Table 3: Amount of Raw Material for Different Types of Cement } \\
Mortar \\
\hline & \multicolumn{5}{|c|}{ Amount } \\
\hline Raw Materials & $\mathrm{N}$ & $\mathrm{B}$ & $\mathrm{C}$ & $\mathrm{BC}$ \\
\hline Sand (75\%) & $281.25 \mathrm{~g}$ & $281.25 \mathrm{~g}$ & $281.25 \mathrm{~g}$ & $281.25 \mathrm{~g}$ \\
\hline Cement (25\%) & $93.75 \mathrm{~g}$ & $93.75 \mathrm{~g}$ & $93.75 \mathrm{~g}$ & $93.75 \mathrm{~g}$ \\
\hline $\begin{array}{c}\text { Calcium Lactate (7\% of } \\
\text { cement) }\end{array}$ & ---- & ---- & $6.5 \mathrm{~g}$ & $6.5 \mathrm{~g}$ \\
\hline Bacillus Subtilis & ----- & Yes & ----- & Yes \\
\hline
\end{tabular}

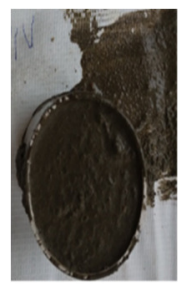

(a) $N$

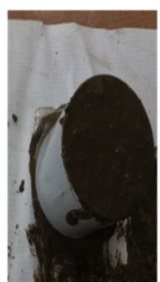

(b) $B$

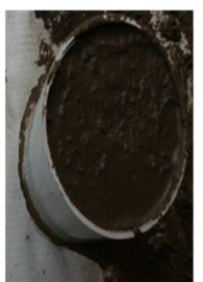

(c) $c$

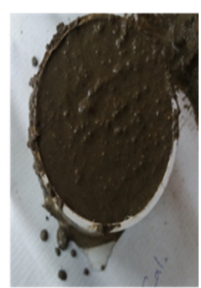

(d) $B C$
Fig. 4: Samples after casting in the molds

(a) Conventional cement samples, (b) Bacterial samples, (c) Calcium Lactate samples, and

(d) Bacteria + Calcium Lactate samples

In B and BC samples addition of bacteria was required. For this purpose, $10 \mathrm{ml}$ water was heated in a beaker using hot plate, heating temperature of $80^{\circ} \mathrm{C}$ was used. On the other hand, take wire loop, heat it until it gets red hot with the help of burner, allow it to cool down and then pick up bacterial colonies with the help of wire loop (Error! Reference source not found.(c)), Mix these bacteria in the beaker water and finally add this water in the B and BC sample's pastes.

The samples were first kept in mold for 24 hours for drying. After removing from the mold samples were immersed in the water for curing. The interrupted curing method was used, the samples were immersed in water for 15 minutes, then the samples were kept in air for one hour and then the samples were immersed in water again for 15 minutes. The process was repeated for 7 days. The samples were kept for curing and were under observation for several days. Finally, the samples were taken for compression testing after 84 days of curing.

\subsection{Analysis for Compression Strength}

Universal Testing Machine (DTU-900HCA, DT\&T) having a maximum load capacity of $30000 \mathrm{kgf}$ was used to test all the cement mortar samples. The crosshead speed was constant i.e. $2 \mathrm{~mm} / \mathrm{min}$ for all samples.
The maximum load values were used to calculate the compressive strengths of the samples by simply dividing them by the cross sectional area.

\section{RESULTS AND DISCUSSION}

\subsection{Comparison of N, B, C and BC Samples after Drying}

Fig. 5(a-d) show the samples after drying and removing from the mould. It was observed that normal (N) sample of cement mortar was failed to show any significant effect, Bacterial (B) sample of cement mortar after curing showed smoothness on the surface. The Calcium Lactate (C) sample showed some white dotted particles on the surface. The bacteria and calcium lactate (BC) sample showed some significant particles in the surface and some micro-porosities in the sample were healed which can be observed by naked eyes.
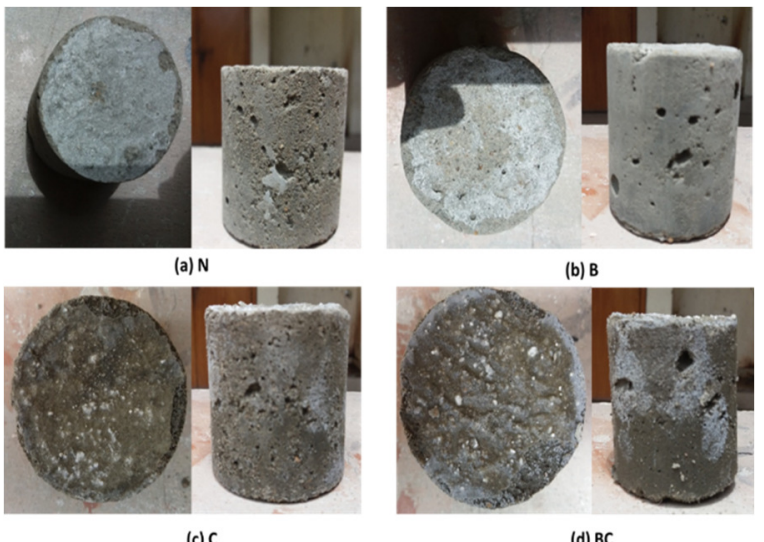

(c) $\mathrm{C}$

(d) $B C$

Fig. 5: Samples after removing from the Molds

\subsection{Comparison of N, B, C and BC Samples on $7^{\text {th }}$ Day of Curing}

After seven days of curing, all samples were again observed to compare these results with the previous ones (Fig. 6(a-d)). The normal sample showed the same morphology as observed in the previous result and the change was noticed. The bacterial sample showed the same morphology as it showed in previous one but the smoothness of the sample was increased. C sample showed same white dotted structure, no further changes were observed in the morphology of the sample. The BC sample showed enrichment in 
white dots in terms of size and also the coverage on top and side surface of sample was increased. This increease in white dots is attriubuted to the bacterial action on the surface when oxygen and water activated bacteria to consume calcium lactate (bacteria + calcium lactate). These white dotted structures indicated that Bacillus Subtilis was growing on the surface which healed some micro voids.

The magnified image in Fig. 7(a-b) is showing that bacteria is making by-product in the form of spheres that were filling the micro voids and thus increasing the density of cement mortar. These spheres were observed in both top surface and sides of the sample. This phenomenon resulted in increasing the compressive strength of cement mortar.
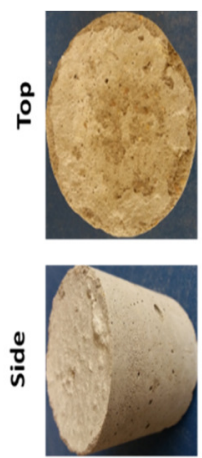

$(a) N$
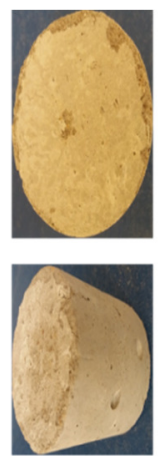

(b) $B$
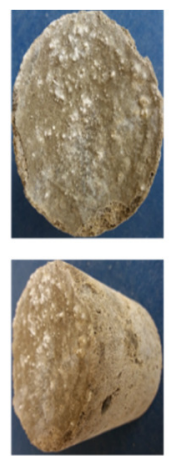

(c) $c$
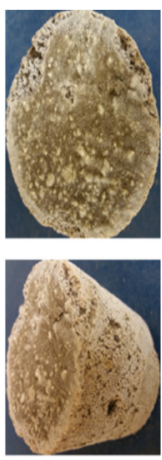

(d) $B C$
Fig. 6: Samples after Seven Days of Curing

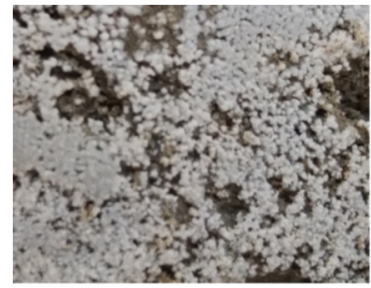

(a) Top Surface

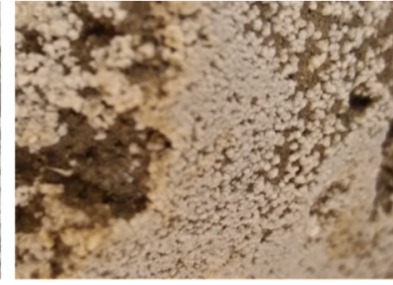

(b) Side Surface
Fig. 7: Magnified Image of Top of BC Sample

\subsection{Comparison of N, B, C and BC Samples on $14^{\text {th }}$ Day of Curing}

After 14 days Fig. 8(a-d)), all samples were examined again to observe any further changes. No change was observed on sample ' $\mathrm{N}$ ' and ' $\mathrm{B}$ ' even after 14 days. The $\mathrm{C}$ sample followed the same trend of increase in white spheres on the surface, which indicated the precipitation of calcium lactate. The BC cement mortar sample showed increase in precipitation of calcium carbonate and the surface layer thickened, some more white dots were also appeared on new areas on the surface.

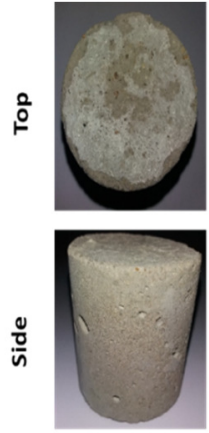

(a) N
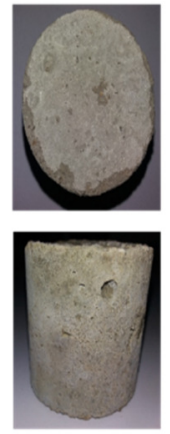

(b) B
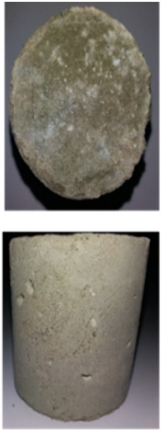

(c) C
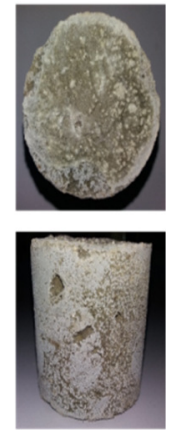

(d) $B C$
Fig. 8: Samples after Fourteen Days of Curing

\subsection{Comparison of N, B, C and BC Samples on $2^{\text {nd }}$ Day of Curing}

Fig. 9(a-d) indicate that no change in morphology were observed in $\mathrm{N}, \mathrm{B}$ and $\mathrm{C}$ samples but for $\mathrm{BC}$ sample which again showed a much more increase in the surface layer with white dotted appearance that indicated the healing of micro-cracks and voids is continued even after 22 days of curing.
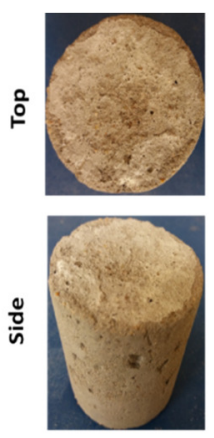

(a) $\mathrm{N}$
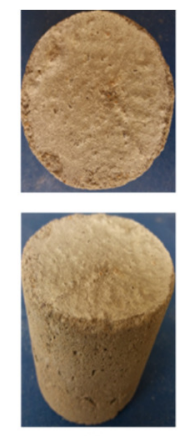

(b) $B$
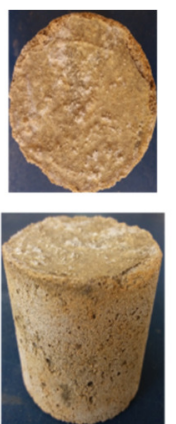

(c) $\mathrm{C}$
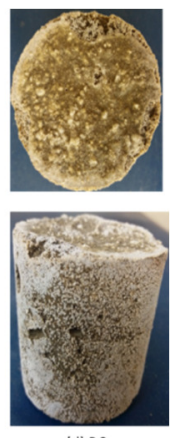

(d) $B C$
Fig. 9: Samples after twenty-two days of curing

\subsection{Comparison BC Samples on Different Days}

As shown in Fig. 10(a-d), the layer on top surface is getting thicker day by day. This shows that bacteria feed calcium lactate and produce layer of calcium carbonate which seals micro void on top surface. It takes almost 2 months to produce complete thick sealed layer on overall cement mortar. 

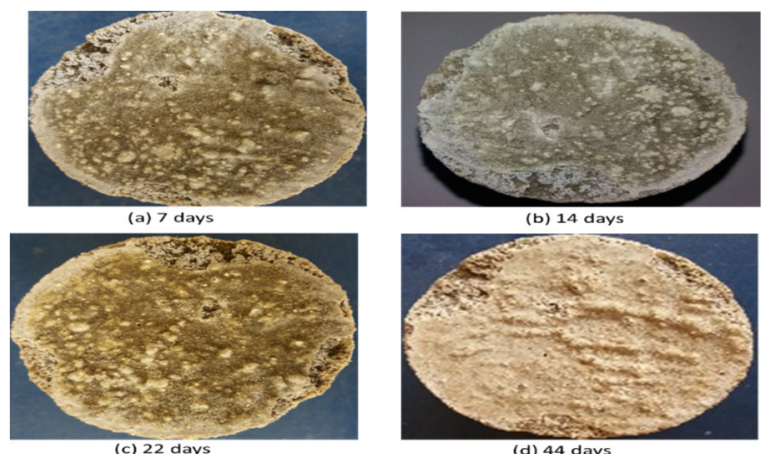

Fig. 10: Comparison of Top of Bacterial + Calcium Lactate Sample

Healing is observed on the sides of BC but it was slower than that of top of BC does. From this experiment it is visualized that calcium lactate did not properly disperse in cement mortar sample and during curing most of its amount came up, that is why healing is easily observed on the top surface but it is difficult to see healing on sides of BC. It is shown in Fig. 11(ac).
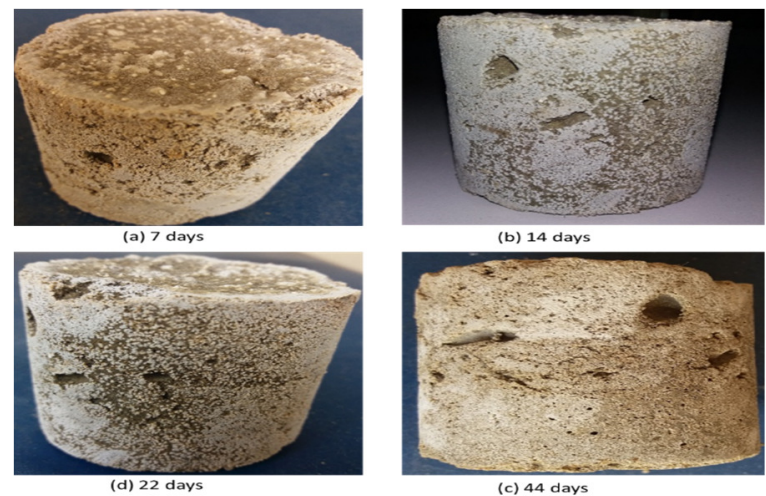

Fig. 11: Comparison of the sides of Bacterial + Calcium Lactate Sample

These results deduced that Bacillus subtilis shows healing phenomenon only when calcium lactate is present as feed, so both are necessary for healing of cracks.

\subsection{Compression Testing}

Figs. 12-13 and Table 4 show the comparison of Normal cement mortar (N), Bacterial cement mortar (B), Calcium lactate cement mortar (C) and Bacterial and Calcium lactate (BC). Samples were tested in the universal testing machine for compressive test after 84 days. $\mathrm{N}$ sample shows the same result as could be expected in conventional cement mortar strength results. B sample shows a little decrease in strength as compared to $\mathrm{N}$ sample that is observed due to the addition of bacteria, and appeared smoothness on the surface. C sample shows a great decrease in strength due to the addition of calcium lactate that is much lighter in weight and weaken the overall structure of the sample. The detrimental effect of calcium lactate on concrete is also reported by Babu and Siddiraju [32]. The effect of calcium lactate on compressive strength of concrete is still unclear, however, researchers have found that its addition has marked effects on the setting time $[33,34]$. In order to study the pure chemical effect of calcium lactate on cement, experiments are needed to be designed in perfect sterile condition, which is technically difficult as the needed heat sterilization may introduce an effect on constituents of concrete. BC sample shows a great increase in compressive strength as compared to other samples. The difference in BC sample is the addition of bacteria and calcium lactate which is responsible for healing of cracks. This increase in strength verified the healing of voids and cracks. These results confirm that the compressive strength of Bacterial and Calcium Lactate (BC) is the highest of all. The sample N, which is composed of cement and sand, is commonly used in construction as cement mortar. Increase in strength of Sample BC, in comparison to Sample N would make it more suitable to be used in construction.

\begin{tabular}{|c|c|c|c|}
\hline \multicolumn{4}{|c|}{ Table 4: Stresses for four samples } \\
\hline Sample & $\begin{array}{c}\text { Load } \\
(\mathrm{kgf})\end{array}$ & $\begin{array}{c}\text { Section Area } \\
\left(\mathrm{mm}^{2}\right)\end{array}$ & $\begin{array}{c}\text { Stress } \\
(\mathrm{Mpa})\end{array}$ \\
\hline $\mathrm{N}$ & 5226.36 & 3848.45 & 13.32 \\
\hline $\mathrm{B}$ & 4332.02 & 3848.45 & 11.04 \\
\hline $\mathrm{C}$ & 734.02 & 2617.54 & 2.75 \\
\hline $\mathrm{BC}$ & 4690.84 & 2617.54 & 17.57 \\
\hline
\end{tabular}

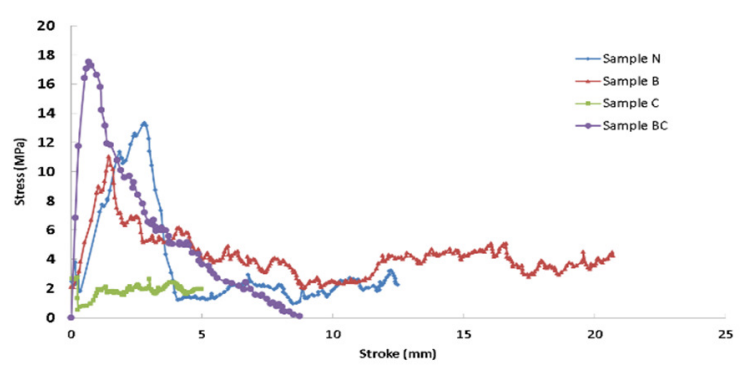

Fig. 12: Strength Comparison of Different Samples 


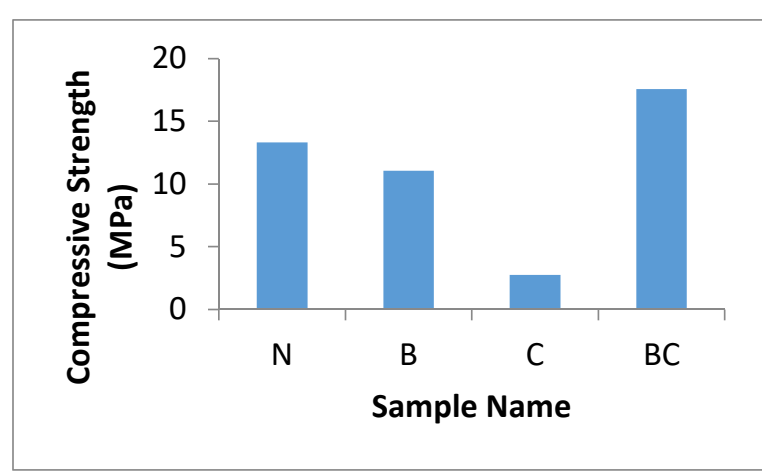

Fig. 13: Bar Chart of Strength Comparison

\section{CONCLUSION}

The present study compared the separate and combined effect of different constituents on the selfhealing effect. The sample $\mathrm{N}$ and sample B did not show any remarkable change in their surface appearance with respect to curing time. It means that the bacteria alone neither increase nor decrease the compressive strength of the cement mortar sample, Sample C, although showed some precipitates due to naturally occurring bacteria in the soil but then the precipitation was stopped soon. Sample $\mathrm{C}$ and Sample $\mathrm{BC}$ did show the precipitation of $\mathrm{CaCO}_{3}$ but for Sample C precipitation was stopped soon while for Sample BC the precipitation was continued for a longer time. The net effect of the addition of Calcium Lactate resulted in decreasing the compressive strength of the sample, if the Calcium Lactate is not converted into $\mathrm{CaCO}_{3}$, this also showed that the naturally occurring bacteria was not sufficient to consume the small amount of $7 \%$ of Calcium Lactate to convert into $\mathrm{CaCO}_{3}$. The results of compressive strength showed that the highest strength was achieved for Sample BC, then Sample N, followed by Sample $\mathrm{B}$, while the lowest strength was displayed by Sample C. This gives an idea that Calcium Lactate which acts as for bacteria has the negative effect on the strength if not consumed and converted into $\mathrm{CaCO}_{3}$. It is therefore suggested to work more on finding the feed source for bacteria that has an individual effect of increasing the strength as reinforcement while at the same time act as feed for bacteria. Naturally occurring calcium sources may be further studied in subsequent studies.

\section{ACKNOWLEDGEMENT}

The authors gladly acknowledge the NED University of Engineering \& Technology, Karachi, Paksistan, for providing all the essential resources/facilities for this research.

\section{REFERENCES}

1. Davies R., Teall O., Pilegis M., Kanellopoulos A., Sharma T., Jefferson A., Gardner D., Al-Tabbaa A., PaineK., Lark R., "Large Scale Application of Self-Healing Concrete: Design, Construction, and Testing", Frontiers in Materials, Vol. 5, No. 51, pp. 1-12, 2018.

2. Huseien G. F., Shah K. W., Sam A. R. M., "Sustainability of nanomaterials based selfhealing concrete: An all-inclusive insight", Journal of Building Engineering, Vol. 23, pp. 155-171, 2019.

3. Ahmed M. L., Javed M. A., Qureshi A. S., "Benefits of Incorporating Induction Furnace Slag in Concrete as Replacement of Cement: A Case Study of Pakistan", Mehran University Research Journal of Engineering and Technology, Vol. 37, No. 4, pp. 701-714, 2018.

4. Mangi S. A., Jamaluddin N.B., Memon S. A., Wan Ibrahim M.H.B., "Utilization of Sawdust in Concrete Masonry Blo cks: A Review", Mehran University Research Journal of Engineering and Technology, Vol. 38, No. 2, pp. 487-494, 2019.

5. Mehmood S., Butt F., "Effect of Steel Fibers on Heat of Hydration and Mechanical Properties of Concrete Containing Fly Ash", Mehran University Research Journal of Engineering and Technology, Vol. 38, No. 1, pp. 83-94, 2019.

6. Lakho N. A., Zardari M. A., Memon N. A., "Effect of Firing on Cracking and Warping of Clay Beams", Mehran University Research Journal of Engineering and Technology, Vol. 35, No. 2, pp. 247-252, 2016.

7. Kanwal H., Arif S., Jawaid M. A., Farooq A., Khan M. A., "Effect on Compressive Strength of Concrete Using Treated Waste Water for Mixing and Curing of Concrete", Mehran University 
Research Journal of Engineering and Technology, Vol. 37, No. 2, pp. 445-452, 2018.

8. Al-Tabbaa A., Lark B., Paine K., Jefferson T., Litina C., Gardner D., Embley T., "Biomimetic cementitious construction materials for nextgeneration infrastructure", Proceedings of the Institution of Civil Engineers - Smart Infrastructure and Construction, Vol. 171, No. 2, pp. 67-76, 2018.

9. Al-Tabbaa A., Litina C., Giannaros P., Kanellopoulos A., Souza L., "First UK field application and performance of microcapsulebased self-healing concrete", Construction and Building Materials, Vol. 208, pp. 669-685, 2019.

10. Wang X., Yang Z., Fang C., Han N., Zhu G., Tang J., Xing F., "Evaluation of the mechanical performance recovery of self-healing cementitious materials-its methods and future development: A review", Construction and Building Materials, Vol. 212, pp. 400-421, 2019.

11. Hu Z.-X., Hu X.-M., Cheng W.-M., Zhao Y.-Y., Wu M.-Y., "Performance optimization of onecomponent polyurethane healing agent for selfhealing concrete", Construction and Building Materials, Vol. 179, pp. 151-159, 2018.

12. Vijay K., Murmu M., Deo S. V., "Bacteria based self healing concrete-A review," Construction and Building Materials, Vol. 152, pp. 1008-1014, 2017.

13. Luo J., Chen X., Crump J., Zhou H., Davies D. G., Zhou G., Zhang N., Jin C., "Interactions of fungi with concrete: Significant importance for biobased self-healing concrete", Construction and Building Materials, Vol. 164, pp. 275-285, 2018.

14. Alazhari M., Sharma T., Heath A., Cooper R., Paine K., "Application of expanded perlite encapsulated bacteria and growth media for selfhealing concrete", Construction and Building Materials, Vol. 160, pp. 610-619, 2018.

15. Sidiq A., Gravina R., Giustozzi F., "Is concrete healing really efficient? A review", Construction and Building Materials, Vol. 205, pp. 257-273, 2019.

16. Ehrlich H. L., "Geomicrobiology: its significance for geology", Earth-Science Reviews, Vol. 45, No. 1-2, pp. 45-60, 1998.
17. Falkowski P. G., Fenchel T., Delong E.F., "The Microbial Engines That Drive Earth's Biogeochemical Cycles", Science, Vol. 320, No. 5879, pp. 1034-1039, 2008.

18. Gerlach R., Lauchnor E., Mitchell A. C., Cunningham A. B., Spangler L., "Engineered applications of ureolytic biomineralization: a review", Biofouling, Vol. 29, No. 6, pp. 715-733, 2013.

19. Boquet E., Boronat A., Ramos-Cormenzana A., "Production of Calcite (Calcium Carbonate) Crystals by Soil Bacteria is a General Phenomenon", Nature, Vol. 246, No. 5434, pp. 527-529, 1973.

20. Zhu T., Dittrich M., "Carbonate Precipitation through Microbial Activities in Natural Environment, and Their Potential in Biotechnology: A Review", Frontiers in Bioengineering and Biotechnology, Vol. 4, No. 4, 2016.

21. Van Paassen L. A., Daza C. M., Staal M., Sorokin D. Y., Van der Zon W., Van Loosdrecht M. C. M., "Potential soil reinforcement by biological denitrification", Ecological Engineering, Vol. 36, No. 2, pp. 168-175, 2010.

22. Fujita Y., Ferris F. G., Lawson R. D., Colwell F. S., Smith R. W., "Subscribed Content Calcium Carbonate Precipitation by Ureolytic Subsurface Bacteria", Geomicrobiology Journal, Vol. 17, No. 4, pp. 305-318, 2000.

23. Rodriguez-Navarro C., Rodriguez-Gallego M., Ben Chekroun K., Gonzalez-Muñoz M. T., "Conservation of Ornamental Stone by xanthusInduced Carbonate Biomineralization", Applied and Environmental Microbiology, Vol. 69, No. 4, 2003.

24. Jonkers H. M. Schlangen E., "Self-healing of cracked concrete: A bacterial approach", In Carpenteri et al. (eds): Proceedings of FRACOS6: Fracture Mechanics of Concrete and Concrete Structures, Catania, Italy, pp. 1821-1826,17-22 2007, June 2007.

25. Ghosh P., Mandal S., Chattopadhyay B. D., and Pal S., "Use of microorganism to improve the strength of cement mortar," Cement and Concrete Research, Vol. 35, No. 10, pp. 1980-1983, 2005. 
26. Santhosh V. R., Ramachandran K., Sookie S. B.,

"Remediation of Concrete Using Microorganisms", Materials Journal, Vol. 98, No. 1, pp. 3-9, 2001.

27. Jonkers H. M., Thijssen A., Muyzer G., Copuroglu O., Schlangen E., "Application of bacteria as self-healing agent for the development of sustainable concrete", Ecological Engineering, Vol. 36, No. 2, pp. 230-235, 2010.

28. Vijay K., Murmu M., Deo S. V., "Bacteria based self healing concrete - A review", Construction and Building Materials, Vol. 152, pp. 1008-1014, 2017.

29. Neeladharan C., Sharpudin J., Loganath V., Jagan B., Chinnaru C., Vijaykaran K.R., "Application of Bacillus Subtilis Bacteria for Improving Properties and Healing of Cracks in Concrete", International Journal of Advanced Research Trends in Engineering and Technology, Vol. 5, No.5, March 2018.

30. Rathnayaka I.R., Review on Self-Healing Concrete with Bacillus subtilis, Proceedings of the Annual International Symposium, Srilanka, 2018.

31. Khaliq W., Ehsan M. B., "Crack healing in concrete using various bio influenced self-healing techniques", Construction and Building Materials, Vol. 102, pp. 349-357, 2016.

32. Babu N. G., Siddiraju S., "An experimental study on strength and fracture properties of self healing concrete", International Journal of Civil Engineering and Technology, Vol. 7, No. 3, pp. 398-406, 2016.

33. Qian M. L. C. X., "Performance of Two BacteriaBased Additives Used for Self-Healing Concrete", Journal of Materials in Civil Engineering, Vol. 28, No. 12, 2016.

34. Paine K., "Bacteria-based self-healing concrete: Effects of environment, exposure and crack size". In Proceedings of the RILEM Conference on Microorganisms-Cementitious Materials Interactions, Delft, Netherlands, 2016. 